\title{
Introduction
}

\section{Understanding human mobility}

\section{Stephen Castles}

In 2015 more than 1.3 million undocumented migrants arrived in Europe, most of them applying for refugee status. Despite wintry weather and rough seas, arrivals hardly diminished from December to February and rose to new peaks once the spring of 2016 led to calmer seas. After Eastern and Central European countries took measures to block the route through the Balkans to Western Europe, large numbers of asylum seekers and other migrants attempted the perilous sea journey across the Mediterranean from Libya to Italy. Despite rescue efforts by Italy and other European countries as well as aid organizations, thousands perished at sea. Most were Syrians, fleeing from the seemingly endless civil war, but there were also many arrivals from other countries experiencing generalized violence and crushing poverty, such as Iraq, Afghanistan and Somalia. Many people arriving in Europe had both protection and economic motivations; in some cases, the latter seemed predominant. That is why European politicians spoke of a 'migration crisis' rather than a 'refugee crisis'.

These developments seem to have taken European governments by surprise, even though asylum-seeker numbers had already grown quite rapidly in 2014. The European response has been piecemeal, uncoordinated and chaotic. German Chancellor Angela Merkel's open door policy in mid-2015 appears to have encouraged the growth in refugee and migrant arrivals and proved unsustainable in the face of opposition from many EU member governments, especially in Eastern and Central Europe.

After a period of initial enthusiasm for supporting refugees, European public opinion shifted towards attitudes of suspicion and even open hostility, with the anti-immigration extreme right making large gains in most countries. Brexit - the surprise victory of the campaign for Britain to leave the European Union in the referendum of June 2016 - was significantly motivated by anti-immigration sentiments. Merkel's party, the Christian Democratic Union (CDU), experienced a big decline in support in regional elections in 2016, with many voters moving to the far-right Alternative for Germany. The German Government brokered a deal with Turkey to keep refugees from moving on to Europe, in return for substantial financial support and a resumption of negotiations for Turkey to join the EU.

Europe was by no means the only region to experience new types of mass migration. As the Washington Migration Policy Institute's (MPI) Newsletter of December 182015 pointed out:

The year 2015 was punctuated by a series of migration crises, from the unrelenting flows of asylum seekers and migrants to Europe's shores and displacement from new and ongoing conflicts in places such as Yemen and Ukraine, to the Nepal earthquake.

Apart from the European events, the MPI mentioned (among other issues) the worldwide escalation of flight from violence and war, which has led to the highest number of displaced 
persons since the Second World War, the political deadlock on immigration reform in the USA and the growth of people smuggling as a new transnational business opportunity.

In Southeast Asia the Rohingya 'refugee crisis' of early 2015 epitomized the difficulties of finding modes of international cooperation where national sovereignty was seen as under threat. The Rohingya are a Muslim minority, who have lived for centuries in areas that now form part of predominantly Buddhist Myanmar. Around 1 million members of this group are considered stateless by Myanmar's government. Up to 140,000 fled to squalid 'displacement camps' following attacks on their communities in 2012, while there are some 32,000 registered Rohingya refugees in camps in neighbouring Bangladesh. For many years, Rohingya have sought to escape discrimination and impoverishment by migrating to Malaysia, Thailand, the Philippines and Indonesia, often paying people smugglers to organize their journeys. In many cases, Rohingya migrants have been ruthlessly exploited by the smuggling gangs, sometimes ending up in slavery-like conditions in remote jungle camps.

In early 2015, the states of the region decided to 'crack down' on the smugglers: boats carrying migrants were pushed back to sea, often with scant supplies of fuel, food and water. In many cases, the smugglers abandoned the boats, leaving the Rohingya to their fate. By May 2015, there were estimated to be between 6000 and 20,000 migrants adrift on the Andaman Sea. Some people had been on the overcrowded boats for three months or more. Finally, some member states of the Association of South East Asian Nations (ASEAN) agreed to allow the boats to land and to provide short-term refuge for the displaced people, on the condition that the international community would fund transit camps and would take responsibility for the repatriation of the irregular migrants to their countries of origin or resettlement to third countries within a period of one year (Palatino, 2015). This year has passed and little has been done to implement these measures; most of the refugees remain in the camps or have moved on to become irregular workers mainly on plantations or building sites.

To give just one more example: the USA experienced a surge in entries of unaccompanied children from Central America and Mexico between October 2013 and August 2015 - US border authorities counted more than 100,000 such entries. Most of the children came from Guatemala, Honduras and El Salvador; countries which experienced generalized violence and impoverishment during and after the civil wars of the 1990s and early 2000s. In some cases their parents were dead or missing, and the children made their own way. In other cases desperate parents encouraged their children to go, in the hope that they would enjoy protection and a better life. The Mexicans were generally sent back, while 77,000 children from Central America were provided with accommodation and schooling in communities throughout the USA. The arrival of these children was met with a mix of solidarity and support on the one hand, and fear and hostility on the other. There were demonstrations against the arrival of refugee children in some communities, often combined with hostility to Mexican immigration in general, despite its crucial importance for the US economy, particularly the agribusiness sector. The result was a growth in anti-immigration populism that was later to feed into Donald Trump's surprise success in the 2016 Presidential Election.

What is striking in these non-European examples, as well as in the European reactions to the Syrian refugee crisis, is the political failure to react appropriately and quickly enough to provide protection to vulnerable people. Indeed, one could argue that once a movement of people is defined as a 'refugee or migration crisis' it is already too late to respond adequately. My purpose in this introduction is not to describe these 'migration crises', important as they 
are in raising awareness of the extent and consequences of international migration, but to examine their significance in understanding the causes of migration and the effects it has on societies both of origin and of destination - the main themes of the essays which make up this book. If we are in fact facing a new and enduring situation, that would make it necessary for states and international agencies to develop long-term strategies - not to seal borders and stop migration, but to address the deep-rooted problems of inequality and conflict.

In the $21^{\text {st }}$ century, the economic, demographic and political drivers of migration are more powerful than ever, yet the public hostility to migration in some receiving countries continues to gain in strength. International and intercontinental flows of labour at all skill levels are crucial to the global economy. Together with other cross-border flows - of commodities, capital, intellectual property and culture - human mobility is an integral part of globalization. Yet states continue to regulate entry of foreigners: border control has become a symbol of national sovereignty. Trump's slogan of building 'a great big wall' to seal the US-Mexico border evoked great resonance among US voters. At a time when governance frameworks for finance, trade and many other aspects of international cooperation have been adopted, global governance of migration remains conspicuous mainly for its absence.

This is a time of change. The 2008 global economic crisis disrupted established patterns of migration. However, migrant settler populations in rich countries have proved more resilient than many expected. At the same time, flows to new industrial areas in Asia, Latin America and Africa have grown. Developed countries and newly-industrializing countries are competing for scarce skills, while even the supply of lower-skilled labour is beginning to appear limited in some areas in view of the demographic transitions taking place in China and elsewhere (Castles et al., 2014). The labour-importing countries - after many years of refusal - have begun to talk to governments of migrant-origin countries through such mechanisms as the UN High Level Dialogue on Migration and Development in 2006 and 2013, and the Global Forum on Migration and Development, which has met annually since 2007.

\section{Why do people migrate?}

Some types of migrants - notably the highly-skilled, and lifestyle and retirement migrants may be able to make individual migration decisions based mainly on expectations of future benefits. But for many migrants, the decision to embark on a difficult and dangerous journey is based more on a pressing need to escape poverty, persecution or violence - or all of these, since they are often closely linked. At the same time there is a hope that migration may lead to a better life, with a higher income, and improved human rights and security. The global diffusion of media products that present an often idealized picture of northern lifestyles reinforces such hopes, and has become a key factor encouraging people to move.

Inequality is a major driver of migration, and both inequality between poor and rich countries (or the Global North and South) and within many nations has increased over the last fifty years (Piketty, 2014). Inequality often works in conjunction with other factors that trigger the decision to embark on difficult and risky journeys, whether in the form of internal or international migration. In many cases, people decide to migrate because their existing livelihood has been destroyed or rendered unviable. For example, the 'Green Revolution' in some less-developed countries (such as India) has increased agricultural outputs, while requiring significant capital outlays and larger farms. The benefits of the higher productivity are accrued by large landowners and multinational agri-business, while small farmers and 
landless labourers often lose their livelihoods. Many move to burgeoning slums in emerging industrial cities (Davis, 2006). Manufacturing - often in the form of sub-contracting for multinationals - has expanded, but job growth in the formal sector is inadequate for the growing urban population, so that many rural-urban migrants have to eke out a living in the informal sector.

The neoclassical economic model of migration is based on the assumption that migration out of areas with labour surpluses and low incomes will in the long run lead to improvements in productivity and wages, so that conditions in origin and destination areas will converge. This implies that more economic development will mean less emigration (Harris and Todaro, 1970). However, this often does not occur in practice: the poor generally lack the resources to migrate to higher wage economies. In addition, fertility rates remain high, especially in Africa, so that more and more young people enter already over-crowded labour markets. Most migrants from poorer regions to the North belong to middle-income groups: farmers with adequate land holdings, small business owners, urban professionals. The benefits of migration - for example in the form of remittances and acquisition of skills - may go mainly to already relatively welloff groups in origin areas, thus exacerbating inequality rather than reducing it. However, some analysts point to the multiplier effects of remittances, arguing that they do strengthen economies and create employment in origin areas. This implies that economic development is likely to lead to more, not less, migration, since the improved situation may provide more people with the resources to move. ${ }^{1}$

'Migration crises', like those mentioned above, occur when conditions in origin areas become so bad that flight is essential. This may be because of civil war and sustained violence (as in the case of Syria) or because of a mix of poverty, lack of employment opportunities, and human insecurity. ${ }^{2}$ Refugees and asylum seekers ${ }^{3}$ are forced migrants who flee their home countries to escape persecution or conflict. The largest category of forced migrants are internallydisplaced persons (IDPs), who are forced to leave their homes, but remain in their country of origin. IDPs are often highly vulnerable as they cannot access international protection. The number of forced migrants worldwide has risen sharply in recent years due to the increasing incidence of conflict and violence. By the end of 2014, 59.5 million individuals were forcibly displaced worldwide as a result of persecution, conflict, generalized violence, or human rights violations. There were 19.5 million refugees, 38.2 million IDPs and 1.8 million asylum seekers (UNHCR, 2015). Displacement continued to increase sharply in 2015, due to conflicts in Syria, Iraq, Afghanistan and several areas of Africa.

It follows from this that emergency migration flows are generally 'mixed flows', which undermine the administrative distinctions made by governments and agencies like UNHCR. Migrant's motivations are complex: they have to leave their place of origin, but also hope to build better lives for themselves and their families in another place.

\section{Neoliberal globalization and migration}

To simplify, one could say that migration is generally the result of a combination of a number of the following factors: inequality, impoverishment, violence and persecution, the development of global labour markets, improved and cheaper transport, the growth of migrant networks, and diffusion of electronic media providing information (or stereotypes) about opportunities in possible destinations. All these factors can be linked to the increasing dominance of the neoliberal model of globalization since the late 1970s. 
Population movements in response to demographic change, the development of trade and production, warfare and conquest, and for cultural and religious reasons have always been part of human history. However, it is my argument in the essays that make up this book that today's migrations have taken on new characteristics in terms of scale, direction, duration and objectives in response to the neoliberal transformation of economies and societies. Since the late 1990s, my research and writing has focused on developing what might be called a 'social transformation analysis of human mobility'. This has proved difficult, since there is no simple connection between the adoption of neoliberal economic principles and the ways in which this has transformed societies.

It is important to understand that the rapid diffusion of open markets for commodities and capital and the commodification of labour and knowledge (Jessop, 2007) have been mediated through a wide and diverse range of cultural and historical experiences and institutions in different places. Human agency has been crucial, with various social and cultural groups developing complex and often contradictory forms of resistance. Global value chains are emerging as a dominant economic form, in which a given product is assembled in one place from components made at many other sites - according to where the necessary combination of labour and capital is cheapest. But that does not mean that the conditions of labour are evened out. Indeed, the massive disparities in pay and conditions are crucial to the neoliberal model of transnational production and financial control.

Global forces can have very different impacts at the national and local level. The challenge to migration researchers today is thus to develop a multi-scalar perspective and to analyse the mediations between global forces and the national and local patterns of transformation and resistance. If there is a common thread to the essays in this collection it is my attempts to do this.

\section{Plan of the collection}

\section{Part I: Theory and methods}

The first chapter 'Understanding Global Migration: a Social Transformation Perspective', discusses theories of the linkages between neoliberal globalization and human mobility. The essay summarizes Karl Polanyi's analysis of the 'Great Transformation' of Europe and North America through industrialization based on the principles of market liberalism. Polanyi argued that the principle of the self-regulation of the market along with the commodification of land, labour and money threatened to destroy the reproductive basis of society, and was met by a 'double movement' of resistance, designed to introduce social and political safeguards to control economic life. This double movement took the form of trade unionism and welfare legislation, but also more extreme political forms such as communism and fascism. The essay goes on to examine the extent to which this theory can be applied to globalization in the late $20^{\text {th }}$ and early $21^{\text {st }}$ century.

The next chapter, 'Migration and Community Formation under Conditions of Globalization' (Chapter 2), examines the ways in which the proliferation of cross-border flows and networks associated with globalization changes the conditions for migrant settlement and community formation. The two main traditional models of migrant incorporation - permanent settler and temporary labour recruitment - are both undermined by new technologies of communication and transport. This leads to a transformation of the material and cultural practices of migrant 
groups, and the emergence of transnational consciousness and communities, which transcend nation-state boundaries. The analysis is illustrated by case studies of a number of Asian and European immigration countries.

Chapter 3, 'Migration, Precarious Work, and Rights: Historical and Current Perspectives' focuses on the world of work, arguing that capitalist economies have always made use of both free and unfree workers, from the era of slavery through to the present day. Schemes for temporary migration, as well as the widespread use of irregular migrant workers, create varying levels of non-freedom and precarity, allowing the dividing up of the workforce according to criteria of gender, race, ethnicity, legal status and national origins.

'Understanding the Relationship between Methodology and Methods' (Chapter 4) examines the approaches which are appropriate for migration research. A clear distinction is drawn between methodology, which relates to the epistomological princples for research, and methods, which refers to the varying ways of collecting data to answer specific research questions. As the chapter states: 'Methodology is our chart to navigate the social world, while methods are the tools of our trade'. The long-standing debate on the principle of objectivity in research versus the idea of social construction of meanings by social actors is revisited, and the significance of methodology for choosing quantitative or qualitiative methods, or a mix of both, is examined. Finally, the chapter discusses the methodological consequences of a social transformation approach to understanding human mobility, and what this means for the choice of methods.

\section{Part II: Global Migration in the $21^{\text {st }}$ Century}

Part II of the collection provides insights into some key characteristics of migration in the contemporary world. 'Guestworkers in Europe: A Resurrection?' (Chapter 5) revisits the debate on temporary labour migration that seemed to have ended in the 1980s. At that time migration scholars and (somewhat later) policy-makers came to recognize that Western European recruitment policies designed to provide temporary labour had actually brought about family reunification, long-term settlement and formation of new ethnic minorities. The chapter examines the differences and similarities between older temporary labour recruitment systems and more recent ones, and looks at the demographic, economic and social pressures that have led the European Union and several of its member states to reconsider temporary migration - albeit in much more limited forms than in the 1960s and 1970s. The growing significance of temporary migration schemes is not confined to Europe: in recent years 'classical immigration countries' like Australia, Canada and the USA have all adopted this approach. I argue that current policies are one-sided: they do provide the labour needed by destination countries, but often neglect both the rights of the migrants and the development objectives of countries of origin. The chapter ends with a discussion of possible alternative approaches, designed to safeguard the interests of both migrants and their home countries, through international cooperation and multilateral governance of migration.

Chapter 6, 'The Factors that Make and Unmake Migration Policies' focuses on the factors that lead to failure or unintended consequences of official policies. Some examples are given of migration policies that have led to outcomes quite different from those originally envisaged. A brief review of 'migration policy in history' shows that the widespread belief in laissez-faire or lack of migration regulation in the past is based on the US experience of the period from 1820 to 1914 , which was actually quite exceptional. A broader perspective reveals that state 
control of departures and arrivals, and restriction of rights of migrants go back through history. I go on to examine three sets of factors that drive migratory processes: factors arising from the social dynamics of the migratory process; factors linked to globalization, transnationalism and North-South relationships; and factors within political systems. I argue that it is the inability (or unwillingness) to recognize these factors on the part of policy-makers that leads to policy failure. Recognizing that migration is a social process that meets important human needs, and that migrants can have a high degree of individual and group agency in shaping migration outcomes, could be a first step towards fairer and more effective policies.

My 'Concluding Remarks on the Climate Change-Migration Nexus' (Chapter 7) from a UNESCO book on Migration and Climate Change is an attempt to sum up the state of knowledge and debate on this important topic. It suggests that the sensationalism which has often accompanied public debate has impeded the search for productive solutions. Three gulfs need to be bridged: the disciplinary divide between environmentalists and migration scholars; the methodological divide between generalized deductive approaches and micro-level research; and the political divide between those who portray 'environmental refugees' as a threat to welfare and security in developed countries and those who seek to defend international legal norms of refugee protection. The growth of empirical research on the significance of climate change for migration in recent years could provide the basis for more productive approaches. The chapter underlines the need to put environmental change into migration studies and human mobility into environmental studies, and goes on to discuss what this could mean.

'Cosmopolitanism and Freedom? Lessons of the Global Economic Crisis' (Chapter 8) questions the cosmopolitan vision, according to which increasingly mobile people develop a global consciousness and move freely across international borders to use their skills, wherever the rewards are highest. The text draws attention to use of 'unfree labour' throughout the history of capitalism. This refers not just to slaves and indentured workers on colonial plantations, but to any group of workers whose rights and opportunities of equal treatment are restricted by inferior legal status, racial discrimination or sexism. In other words: there are many different types and degrees of unfreedom for workers. From the 1970s, the emergence of the neoliberal global economic order, based on open borders, free markets, a small state and deregulation, restructured labour markets hierarchies on a world scale, leading to new categories of disadvantaged or relatively unfree workers. Types of employment which have proliferated include subcontracting, temporary employment, casualization and informalization. These forms of marginalization can be summed up in the notion of precarious work. This restructuring of labour relationships had profound effects on migrant workers during the global economic crisis that started in 2008. Interestingly, both migrant unemployment and employment grew during the recession. The explanation for this can be found by looking at the different effects of the crisis on male and female migrant workers.

'International Migration at a Crossroads' (Chapter 9) discusses the dilemmas of international migration in the context of increasing concerns about security since 2001 . The securitization of migration is based on a dominant perspective that emphasizes the security of the rich countries of the Global North, while ignoring the lack of human security in the Global South. Poverty, hunger, violence and lack of human rights are often the result of past colonization and more recent military interventions. Migration should be seen primarily not as a threat to state security in the North, but as a result of the human insecurity that arises in the South through 
global inequality. An alternative way of looking at this situation is to be found in Amartya Sen's principle of 'development as freedom' - according to which the right to be mobile is a basic freedom that can enhance individual capabilities and the innovation capacity of societies. The essay goes on to examine some key issues in international migration, including the effects of the global economic crisis, and the global governance deficit.

\section{Part III: Migration and development}

This part of the collection comprises three texts, written between 2008 and 2011, at a time when I was working closely with Raúl Delgado Wise, then Director of the development studies program at the Autonomous University of Zacatecas (Mexico). Chapter 10, 'Comparing the Experience of Five Major Emigration Countries', arose from a joint workshop we held at the conference centre of the Rockefeller Foundation in Bellagio (Italy), with a government official, a representative of a migrant association and a researcher from each of five countries: India, Turkey, the Philippines, Morocco and Mexico. The contrasting trajectories of the five origin countries help us in understanding the important role of differing cultures, political structures and historical experiences (for instance of colonialism), in shaping adaptation and resistance to neoliberal globalization.

'Development and Migration or Migration and Development: What Comes First?' (Chapter 11) addresses a question which apparently makes little sense, since the two processes are clearly closely linked. Yet in public debates, politicians continue to promote the idea that an important reason for supporting development efforts in the Global South is that this will reduce migration to the North. This carries the implication that South-North migration is undesirable, and that poor people should stay put - an attitude characterized by Oliver Bakewell as 'the sedentary bias' (Bakewell, 2008). In fact, the idea that development reduces migration is mistaken: researchers have found that one of the first effects of economic growth in the South is to increase the number of people who have the resources to move. Moreover, mobility of people from one developed country to another is very frequent, and generally seen as beneficial, since it ensures optimal use of human capital. Development leads to more migration, not less. The article puts forward an alternative view of migration as a normal part of human development and social transformation.

Chapter 12, 'Bringing Human Rights into the Migration and Development Debate' reflects the experiences of critical civil society groups that have participated in the Global Forum on Migration and Development (GMFD) - an intergovernmental meeting organized annually since 2007 under the auspices of the United Nations. The annual meetings have made resounding declarations on improving the governance of migration and safeguarding the rights of migrants, but cannot make binding decisions and seem to have had little effect on national policies. The GMFD includes a forum for civil society organizations, but many of them have found the experience quite frustrating. In 2010, one such organization - the People's Global Action on Migration, Development and Human Rights (PGA) - published a critical report entitled Reframing the Debate on Migration, Development and Human Rights: Fundamental Elements (Delgado Wise et al., 2010). The chapter summarizes some of the ideas of the PGA and puts them in the context of struggles to establish global governance frameworks for migration. It is sobering to realize that, despite its weakness, the GMFD is the first real attempt at intergovernmental dialogue on international migration. 


\section{Part IV: Asylum and refugees}

Part IV of the collection owes much to my period (2001-2006) as Director of the Refugee Studies Centre at the Univeristy of Oxford, and to what I learnt from staff and students at the RSC and other migration research centres at Oxford. 'Global Perspectives on Forced Migration' gives an overview of displacement, which covers not only people who have crossed international borders in search of protection (refugees and asylum seekers), but also people displaced internally by violence, persecution, natural disasters and development projects such as dams or airports, which destroy their habitat. With the end of the Cold War, there was a widespread expectation of a 'peace dividend': a decline in war and violence and therefore a reduction in forced migration. In fact conflict and displacement have continued to increase according to the UN Commissioner for Refugees (UNHCR, 2015), 2014 recorded the highest levels of displacement since WWII, and 2015 and 2016 will probably set new records. The chapter argues that conflict and forced migration are an integral part of the social transformations arising from globalization.

Chapter 14, 'The International Politics of Forced Migration' also provides a global overview of forced migration, but focuses particularly on the political debates and interests which have shaped policy responses to changing forms of forced migration since the 1940s. The development of the international refugee regime through the Cold War, the period of colonial liberation in the 1950s and 1960s, and the 'asylum crisis' of the 1980s and 1990s is the central theme. Finally, the chapter analyses the effects of globalization on forced migration, and the emergence of a regime based on 'containment' - that is, keeping refugee populations in the Global South in order to reduce the 'burden' on rich countries. The refugee influx to Western Europe in 2015 and 2016 may well signal the end of the politics of containment, although the deal struck between the EU and Turkey can be seen as an attempt to achieve containment in new ways.

'Root Causes' (Chapter 15), jointly authored by Nicholas Van Hear and myself, ${ }^{4}$ examines policy approaches intended to address the fundamental causes of migration. Implicitly based on the idea that South-North migration is harmful, but cannot be limited through border control alone, governments and intergovernmental organizations have put forward measures designed to deal with causal factors in origin countries, especially violence, human rights violations, inequality and poverty. Since the 1990s, these discourses have been closely linked to two other debates; first that on 'mixed flows' in which refugees and economic migrants flee the same countries, may have mixed motivations (that is, they seek both protection from violence and better livelihoods) and are often indistinguishable; and second that on the possible benefits of migration for economic development. Addressing root causes has thus come to imply measures to bring about forms of development seem as beneficial by governments of rich nations and intergovernmental organizations. In extreme cases, measures can even include military intervention designed to transform societies in ways thought likely to reduce refugee and migrant outflows. However, the overwhelming experience has been the failure of attempts at state- and nation-building through external intervention in such countries as Afghanistan, Iraq, Somalia and Libya.

\section{Part V: Citizenship and identity}

This final part of the collection deals with the last stage of the migratory process: the incorporation of immigrants into the societies of destination countries and what this can mean 
for identity, citizenship, inter-group relations and welfare systems. Chapter 16, 'Transnational Communities: A New Form of Social Relations under Conditions of Globalization', examines the idea that past principles of assimilation or integration into host societies are no longer relevant, because improvements in transport and communications mean that people can stay in touch with their origin countries over long periods and vast distances, and thus develop a transnational consciousness. I argue that trasnational communities are an important and growing phenomenon, but that most migrants still do see themselves either as settlers or temporary sojourners. Moreover, transnational identities are complex and contradictory, and may complement existing models of immigrant incorporation or work against them. Overall the growth of transnational communities does make it necessary to rethink some basic principles of democratic polities, such as the model of singular and exclusive nation-state citizenship. Recognition of dual or multiple citizenship and portability of welfare rights are among the issues that need to be addressed in an increasingly mobile world.

'Nation and Empire: Hierarchies of Citizenship in the New Global Order' (Chapter 17) is concerned with the challenges to the nation-state model which arise through globalization and increased mobility of people across national borders. The chapter starts by looking at some of the contradictions that have always existed in nation-state citizenship, and then examines how such contradictions have been exacerbated by transnationalism and mobility. The most distinctive feature of the new global order is that the overwhelming majoity of polities now define themselves as nation-states: membership of the United Nations has increased from 50 in 1945 to 193 today. For the first time in history, the majority of the world's people are defined as citizens. Everyone can get a passport, but not all passports are equal. Being a citizen of a rich northern state gives one the right to cross nearly every border, but holders of passports of poorer less-developed countries may find many borders closed to them. There is a hierarchy of nation-states and a hierarchy of citizenships which in turn shapes the legal status and rights of migrants and ethnic minorities. The chapter closes by discussing the possibility of moving from hierarchical citizenship to new democratic forms of transnational citizenship.

'The Myth of the Controllability of Difference: Labour Migration, Transnational Communities and State Strategies in the Asia-Pacific Region' (Chapter 18) discusses whether the erosion of national borders, the emergence of multicultural societies and the growth of transnational communities observed in western countries of immigration is also to be expected in labour-importing countries of the Asia-Pacific regions. Although the region has a long history of migrations, large-scale labour migration is fairly new, as some economies experience rapid growth, while others become labour reserves. Asian politicians tend to see migrant workers as temporary sojouners, whose presence will have no effect on social, cultural or political patterns. However, there is already evidence of family reunion and long-term settlement. Moreover, structural dependence is emerging, as labour markets become more differentiated, with certain jobs - such as plantation labour, domestic work and construction - seen as 'migrant work', which is avoided by nationals. Informal factors, such as the growth of the migrant networks and the emergence of transnational communities, as well as the highly profitable migration industry, also perpetuate migration flows, even when governments try to restrict them. The danger is that the failure of policy-makers to recognize these powerful forces will lead to social exclusion of migrants, with negative consequences not only for them but for society as a whole.

The final chapter, 'Migration, Minorities and Welfare States', by Carl-Ulrik Schierup 5 and myself examines the relationship beween welfare states and labour migration. The focus is on 
western Europe, but attention is also paid to influences from the USA. Varying types of European welfare states helped set the conditions for differing forms of migration and minority formation from the 1950 s to the 1970s. After the 'oil crisis' of the mid-1970s, the rise of neoliberalism led to major cuts in welfare programmes and services, with migrants and minorities often bearing the brunt of the changes. The differentiation of populations on the basis of ethnicity, origins and legal status has complemented existing hierarchies based on class, gender and location, and has helped in securing public assent to neoliberal reforms. In the long run, this has led to a deterioration of working conditions and pay for all workers, and to growing class inequality, which in turn undermines citizenship and identity. In its attempts to move towards common approaches to welfare, the European Union now has to resolve two major contradictions: first that between its economic and political goals; and second that between adjustment to the economic imperatives of global capitalism and the task of generating a new European identity based on a powerful notion of citizenship.

\section{Notes}

1. For a small selection of the many contributions to the migration and development debate and further references see: Bakewell (2009); Castles and Delgado Wise (2008); de Haas (2010); Delgado Wise et al. (2010); Içduygu (1998); Skeldon (1997).

2. A report published by the UNDP characterizes the causes of human insecurity as 'threats to socio-economic and political conditions, food, health, and environmental, community and personal safety' (Jolly and Ray, 2006).

3. A refugee is defined by the 1951 United Nations Convention Relating to the Status of Refugees as a person residing outside his or her country of nationality, who is unable or unwilling to return because of a 'well-founded fear of persecution on account of race, religion, nationality, membership in a particular social group, or political opinion'. Asylum seekers are people who have crossed an international border in search of protection, but whose claims for refugee status have not yet been decided.

4. Nicholas Van Hear of the Centre of Migration, Policy and Society (COMPAS) at the University of Oxford has given permission for reproduction of this chapter in the collection.

5. Carl-Ulrik Schierup of the REMESO migration research institute at Linköping University, Sweden has given permission for reproduction of this chapter in the collection.

\section{References}

Bakewell, O. (2008) 'Keeping Them in Their Place: The ambivalent relationship between development and migration in Africa'. Third World Quarterly, 29:7, 1341-58.

Bakewell, O. (2009) South-South Migration and Human Development: Reflections on African Experiences UNDP Human Development Reseach Paper 2009/07. (New York) http://hdr.undp.org/en/reports/global/hdr2009/.

Castles, S., de Haas, H. and Miller, M.J. (2014) The Age of Migration: International Population Movements in the Modern World (fifth editon) (Basingstoke: Palgrave Macmillan).

Castles, S. and Delgado Wise, R. (eds) (2008) Migration and Development: Perspectives from the South (Geneva: International Organization for Migration).

Davis, M. (2006) Planet of Slums (London and New York: Verso).

de Haas, H. (2010) 'Migration and development: a theoretical perspective'. International Migration Review, 44:1, 227-64.

Delgado Wise, R., Covarrubias, H.M. and Puentes, R. (2010) Reframing the Debate on Migration, Development and Human Rights: Fundamental Elements (Mexico City: People's Global Action on Migration, Development and Human Rights).

Harris, J.R. and Todaro, M.P. (1970) 'Migration, unemployment and development: a two-sector analysis'. American Economic Review, 60:1, 126-42.

Içduygu, A. (1998) 'Thirty-seven years after: consequences of emigration for Turkey’ (Department of Political Science, Bilkent University, Ankara. Unpublished paper).

Jessop, B. (2007) 'Knowledge as a fictitious commodity: insights and limits of a Polanyian perspective', in Bugra, A. and Agartan, K. (eds), Reading Karl Polanyi for the Twenty-First Century: Market Economy as a Political Project, (Basingstoke: Palgrave Macmillan) 116-33. 
Jolly, R. and Ray, D.B. (2006) The Human Security Framework and National Human Development Reports (New York: United Nations Development Programme (UNDP)). http://hdr.undp.org/en/media/NHDR_Human_Security_ GN.pdf.

Palatino, M. (2015) ASEAN's Response to Rohingya Crisis Falls Short The Diplomat. (Tokyo: The Diplomat) http:// thediplomat.com/2015/06/aseans-response-to-rohingya-crisis-falls-short/, accessed $21 \mathrm{March}, 2016$

Piketty, T. (2014) Capital in the Twenty-First Century (Cambridge, Mass. and London: Belknap Press of Harvard University Press).

Skeldon, R. (1997) Migration and Development: A Global Perspective (Harlow, Essex: Addison Wesley Longman).

UNHCR (2015) UNHCR Global Trends: Forced Displacement in 2014 (Geneva: United Nations High Commissioner for Refugees). http://www.unhcr.org/556725e69.html. 